\author{
Christiaan Swanepoel \\ Christiaan Swanepoel is Professor \\ Emeritus of University of South Africa, \\ Pretoria, South Africa, Research \\ Fellow in African Languages, and \\ served five years as vice-principal \\ academic and research before \\ retirement. He is a member of the \\ Academy of Science of South Africa. \\ Email: swanecf@vodamail.co.za
}

\section{Thomas Mofolo's sentence design in Chaka approached in translation}

\title{
Thomas Mofolo's sentence design in Chaka approached in translation
}

Mofolo's sentence design in Chaka is a challenge to the translator, not only because of the significant length of the sentences, but in particular for the extensive use of the semicolon, appearing within sentences of "paragraph-length". This prompted the suggestion that it be referred to as the "semicolon phrase". This article explores this stylistic feature, amongst others by responding to several compelling questions, ranging from how five translators of the work approached it in their respective languages, possible attitudes and influences, and likely intentions on the part of the author. With regard to the question of how the semicolon phrase should be approached in translation, it is argued that the topography of the page vests in the author who is licensed to shape the text as s/he wishes. Punctuation marks, however, appear to be more negotiable than narrative content, though the shape of the source text should be respected as far as possible. At the same time the target text needs to be approached in accordance with the conventions at work in the target language. The result is a challenging balancing act requiring considerable discretion. Keywords: literary translation; topography of the page; punctuation marks; source language (SL); target language (TL).

\section{Introduction}

Sentence design in this paper will be approached as a narrative facility novelists explore for creative purposes, and only marginally in terms of its linguistic or syntactic significance. Hence it is preferred to refer to sentence "design" instead of sentence "structure". Chapters, paragraphs and sentences of varying sizes and relative lengths, as well as punctuation marks such as the comma, semicolon, en dash, colon, question mark, and full stop are some of the standardised means novelists use to manage their sentences on the surface of the page in creating the narrative impact they sought.

Extended paragraph-length sentences, well punctuated with semicolons and commas, characterise the topography of the page in the novel, Chaka, and enable Mofolo to create a flowing, lofty narrative, for which he has been admired ever since the book's first appearance in 1925. Although at first sight a less problematic aspect of the translation process, the paragraph structure has been handled differently by translators. This raises several questions. Firstly, what is meant by the concept "paragraph-length sentence", and how did other translators handle it (see Dutton, and Kunene both translating into English; Ellenberger into French; and Sulzer into German)? Secondly, how consistently does the paragraph-length sentence occur? Thirdly, did Mofolo deliberately challenge traditional conceptions about sentence 
demarcation? Fourthly, was he perhaps influenced by the style of (a) his own earlier novels; or (b) his contemporaries writing in Sesotho; or (c) by the world literature he probably had access to, such as the Bible and Victorian novelists Haggard and Corelli? Fifthly, can current literary translation theories and practices contribute to a solution to the challenge, one that is respectful of both the author's narrative pursuits and prevailing conventions at work in the target language (TL)? Sixthly, how should his style be approached in translation? These six questions are the challenges this article will seek to address in an attempt to consider how to attain a worthy representation of the great novelist.

In my initial Afrikaans translation (Mofolo, Tjhaka) I departed from Mofolo's approach by using shorter sentences and breaking up certain paragraphs, resulting in a sustained dynamic representation. Now, forty years later, I am of the opinion that this might have been too marked a departure from the author's license to manage his narrative. An as yet unpublished second Afrikaans translation (Mofolo, ChakaDie Nuwe Afrikaanse Vertaling) follows the original as consistently as possible, yet, in comparison with the first, might have sacrificed pace.

\section{What is a paragraph-length sentence? How have other translators handled it?}

The concept "paragraph-length" sentence plainly refers to a sentence of the length or size of a paragraph, in which the most salient feature of punctuation is the semicolon. This does not imply that all Mofolo's sentences in this novel are paragraph-length, although a fair number do appear as paragraphs. ${ }^{1}$ Some of these sentence paragraphs are short, and some do not contain even a semicolon. In a limited number of cases they occur as the opening or closing sentences of chapters, such as of chapter 8 (both opening and closing, 51 and 58), or chapters 20 (closing, 141) and 26 (opening, 164).

The sentence length I refer to occurs repeatedly within larger paragraphs with appropriate punctuation marks such as semicolons, commas, and to a much lesser extent the en dash, colon or exclamation mark. This mode of narrative management is of course not strange or extraordinary. The topography of the page, i.e. the surface layout of paragraphs, sentences and their internal subdivisions, or "the fixed spatial organisation of the page and the book" (Foley 5), is the sole operational domain of the novelist and s/he is entitled to work according to her/his artistic inspiration and style. In Mofolo's case the challenge for the translator is: (a) the extent to which he prefers to use consecutive semicolons interspersed with commas instead of a full stop; (b) the relatively consistent way in which he does so right through the novel; and (c) the fact that the translator might prefer to break the semicolons up into sentences because, in her/his view, a new thought is introduced and might warrant a fuller break; or in her/his interpretation of the TL and its conventions of punctuation, a full stop would be more appropriate-whereas the extensive succession of semicolons could come across as either long-winded or even awkward in the TL. 
The best way to clarify my point is perhaps to illustrate it with an example. Chapter Two of the novel communicates the fact that the news did leak out that Chaka was begotten through a relationship of bonyatsi (an illegitimate affair), instead of from one of his father Senzangakhona's senior wives, as custom dictates, and that people started to talk about it. Let me quote it in Sesotho first, and then compare various translations in accordance with the problems stated above:

Ditaba ha di timanwe e se bohobe; leha Senzangakhona ditaba tsa hae le Nandi a ne a di patile haholoholo, empa ho tsejwa di ile tsa tsejwa; leha di tsa ka tsa hlahela hantle, empa batho ba ne ba di tseba, ba di seba; mme yare mohla ba di utlwang, ba qala ho hloya Nandi le Chaka ka tlhoyo e tshabehang, ba dumellana le mafumahadi hore morena ke Mfokazana; empa bona ba hla ba rata eka Chaka a ka bolawa, hobane ke ngwana wa sebe, hoja bonyane ke ngwana wa bonyatsi. (Mofolo, Chaka (RSA Orthography) 14) ${ }^{2}$

Stories do get around because they are not bread; although Senzangakhona hid his affair with Nandi very well, it did become known; although it did not become known very well, people knew it and gossiped about it; and from the day they heard it, they started to hate Nandi and Chaka with a terrible hatred, and they agreed with the senior wives that the king is Mfokazana; but they also wished that Chaka could be killed, because he is a child of sin; had he rather been a concubine's child. (My free translation)

This is an example of one of Mofolo's paragraph sentences which he breaks up with four semicolons. For the sake of clarity I suggest we henceforth call them "semicolon phrases". In Mofolo's usage they are not only fully formed conventional sentence that could stand on their own; they are "complex" rather than so-called "simple", each of them introduced by a conjunction: leha (although/though); leha (once again); mme yare (two of them used consecutively, meaning "and" and "when"); and empa (but). Within themselves the semicolon phrases are punctuated by commas to further complete (and complicate) the topography of the sentences. It is only at the end of the paragraph that Mofolo closes with a full stop. In order to get a clearer grip on each of the semicolon phrases it is useful to isolate them as follows:

Ditaba ha di timanwe e se bohobe;

[;] leha Senzangakhona ditaba tsa hae le Nandi a ne a di patile haholoholo, empa ho tsejwa di ile tsa tsejwa;

[;] leha di tsa ka tsa hlahela hantle, empa batho ba ne ba di tseba, ba di seba;

[;] mme yare mohla ba di utlwang, ba qala ho hloya Nandi le Chaka ka thoyo e tshabehang, ba dumellana le mafumahadi hore morena ke Mfokazana;

[;] empa bona ba hla ba rata eka Chaka a ka bolawa, hobane ke ngwana wa sebe, hoja bonyane ke ngwana wa bonyatsi.

The first translation is from Dutton's English text (Mofolo, Chaka, an Historical Romance 12-13): 
There is a proverb, "Scandal is not like bread: there is never any shortage", and though Sezangakhona had hidden so carefully his affair with Nandi yet it was certainly known, and although it was not common knowledge all the same people knew of it and alluded to it. And as soon as men heard of the charge they hated Chaka and Nandi with a fearful hatred and agreed with Senzangakhona's wives that Mfokazana was the heir, and they even wanted Chaka to be killed as being born of sin: he was only a child, but he was illegitimate.

Dutton translates all four conjunctions with "and" but differentiates their punctuation first with two commas, then with a full stop, and then again with a comma. He does not make use of any semicolons. He uses a colon in the final section to substitute Mofolo's conjunction hobane and another "and" for Mofolo's conjunction hoja (if; when). Dutton thus only makes one full stop break in comparison with the original.

The second translation is by Ellenberger (Mofolo, Chaka, une épopée Bantoue 27) into French, which appeared in 1940:

Les nouvelles, dit-on, ne sont pas du pain, personne n'en est avare: Senzangakhona avait pris grand soin de cacher son aventure avec Nandi, mais bientôt tout de monde en eut connaissance. On en parlait à mots couverts, mais, tout de monde étant au courant, les cancans allaient leur train... Lorsque la chose fut ébruitée, elle provoqua un movement d'animosité envers Nandi et Chaka, suscitant meme contre eux une terrible haine. L'on était d'accord avec ces dames de la cour pour affirmer que dans l'ordre de succession M'fôkazana venait en première ligne, mais on allait plus loin encore puisqu'on disait, et cela venait d'elles, que ce serait bien faire que de tuer Chaka, l'enfant du péché; tout au moins eût-on pu accepter le fruit d'une aventure momentanée!

Ellenberger uses a colon after the proverb where Mofolo uses a semicolon and so avoids Mofolo's conjunction. He ends Mofolo's semicolon phrase with a full stop. At the end of the following semicolon phrase he uses three dots which suggest that he opens the possibility for the reader to use her/his imagination to fill in what the gossip could imply for the king. Ellenberger ends Mofolo's next semicolon phrase with a full stop. In the final semicolon phrase he avoids Mofolo's conjuction hobane by using a comma to translate the perception the people held that Chaka was l'enfant du péché (a child of sin). Here he inserts a semicolon to translate the last part of the paragraph with the statement that the boy was conceived as the fruit of a "momentary adventure" (aventure momentanée). In this paragraph we notice that Ellenberger afforded himself a great degree of freedom in comparison with the punctuation in the original.

The third translation is from Kunene (Mofolo, Chaka-A New Translation of the Famous Novel 11) into English, which appeared in 1981:

Gossip is not like bread, so no one withholds it from another. Therefore, even though

Senzangakhona kept his scandal with Nandi a dead secret, it did get to be known, 
and though it was not publicly exposed, people nevertheless knew it and gossiped about it. From the time they first heard it, they began to hate Nandi and Chaka with a fearful hatred, and they agreed with the royal wives that Mfokazana was the rightful successor to the kingship. They, however, went even further and wished that Chaka should be killed, for he was a child of sin, and they declared that it would have been much better if he had been the child of a concubine.

Kunene replaces Mofolo's first semicolon with a full stop. When he starts the next semicolon phrase, he adds the adverb "therefore", and follows it up with two further adverbs "even though", so as to enable him to join this semicolon phrase with Mofolo's next one, which he then ends with a full stop. The following semicolon phrase Kunene again ends with a full stop and then runs to the end of the paragraph using commas, but prefers to offer an explanation of Mofolo's hoja ke ngwana wa bonyatsi when translating "and they declared that it would have been much better if he had been the child of a concubine".

Then there is the German translation, by Sulzer (Mofolo, Chaka Zulu 24-5) published in 1988:

"Skandalgeschichten gehen nie aus, anders als das Brot". Obgleich Senzangakhona seine Geschichte mit Nandi ganz und gar verheimleicht hatte, war das Wissen um sie in der Luft; obschon sie nicht voll ans Tageslicht gedrungen war, wußten die Leute von sie und tuschelten darüber. Als aber die Geschichte ruchbar wurde, fingen sie an, Chaka und Nandi mit abscheulichem Haß zu hassen. Sie stimmten mit dem Großfrauen darin überein, daß Mfokazana Häuptling werden solle, aber sie wünschten darüber hinaus den Tod Chakas, den er sei ein Kind der Sünde-ware er wenigstens bloß ein Kind der Schande gewesen!

Sulzer's punctuation follows a pattern that by turns differs from and agrees with the other translators. There is a full stop after the opening semicolon phrase, replacing Mofolo's semicolon; but Sulzer follows Mofolo with the next semicolon phrase. Thereafter he also links the last two semicolon sentences by cutting away from the conjunction empa (but) which Mofolo preceded with a semicolon, and then uses a dash for introducing what the people thought-that it would have been better if Chaka could be killed owing to his illegitimate conception.

My 1974 Afrikaans translation (Mofolo, Tjhaka 9) reads:

Maar gerugte het versprei. Senzangakhona het die sake van hom en Nandi baie goed probeer wegsteek, maar bekend het dit geword. Hoewel dit nie goed bekend geraak het nie, het die mense dit tog te wete gekom en daaroor geskinder. Namate dit tot hulle deurgedring het, het hulle Nandi en Tjhaka begin haat met ' $n$ liederlike haat. Hulle het met die vroue saamgestem dat Mfokazana die kaptein is. Hulle het ook begeer dat Tjhaka doodgemaak moet word omdat hy 'n seun van die sonde was. 
I replaced Mofolo's semicolons consistently with full stops and even added a full stop to replace Mofolo's comma after ka thoyo e tshabehang (with a fearful hatred) in the second last semicolon phrase. Mofolo's semicolon phrase is thus broken up into two sentences. I did not translate the proverb with which the paragraph opens as Dutton, Ellenberger, Kunene and Sulzer did. Nor did I translate the last part of the paragraph, hoja bonyane ke ngwana wa bonyatsi.

My 2015 manuscript translation (Mofolo, Chaka-Die Nuwe Afrikaanse Vertaling 28) reads:

Stories lek uit en kan nie soos brood weggesteek word nie. Senzangakhona het die storie oor hom en Nandi baie goed probeer wegsteek. Maar bekend het dit geword. Ofskoon dit nie goed bekend geraak het nie, het mense dit tog te wete gekom en daaroor geskinder. En vandat hulle dit gehoor het, het hulle Nandi en Chaka begin haat met ' $n$ vreeslike haat, en met die senior vroue saamgestem dat Mfokazana die koning is. Hulle het inderdaad selfs gewens dat Chaka doodgemaak kon word omdat hy ' $n$ kind van die sonde was; was hy maar liewer 'n skelmpie se kind.

In the new translation I again use four full stops, but break the sections differently from the previous version. The comma in Mofolo's second semicolon phrase is replaced with a full stop, and a new sentence is thus formed with Maar bekend het dit geword (empa ho tsejwa di ile tsa tsejwa). In this translation I did translate the opening proverb by focussing on its meaning and adding the proverb's comparison of "stories" and "bread", which was omitted in the first. This time I also translated the last part of the paragraph, hoja bonyane ke ngwana wa bonyatsi with was hy maar liewer ' $n$ skelmpie se kind (directly translated it means "had he rather been a concubine's child"); but here I used a semicolon (a) to separate the two "was-es" and (b) to give clarity on Mofolo's added point that the problem would have been less if the boy was born from a concubine, since he then would have had no right of succession.

It becomes clear from this investigation that the five translations all preferred to punctuate the paragraph differently from Mofolo. This is probably because they deemed it more appropriate to the conventions of punctuation in their respective target or host languages and for their audiences. It could also be owing to the way they understood the original text, and how they preferred to interpret the contents of the paragraph. In my case, it is also tied up with what I as the translator deemed important within the set of events that is being narrated, and therefore I needed the punctuation to point up the relevant facts for the Afrikaans reader who might not sense the cultural background completely. This might be the case with the other translators as well. The structural nature of these semicolon phrases-being in fact well-formed complex sentences-also "invites" their being broken up into fully formed sentences. 
Did Mofolo deliberately challenge traditional conceptions about sentence demarcation?

This is difficult to confirm. Mofolo did not eschew the use of punctuation marks; he merely made considerably more use of the semicolon to fit his style. In fact, it seems more likely that he could have had a global understanding of both "the sentence" and "the paragraph"; that his narrative used particular syntactic structures at specific points in line with his overarching project in Chaka. In the paragraph we have considered, his main focus had been on the leaking of the information about Nandi's impregnation by the king: that the relationship began outside of official wedlock; that it was kept secret; and that serious consequences were looming for the mother and for the son. This Mofolo probably wanted to be viewed as one coherent piece of narrative, and he consequently preferred to punctuate the paragraph accordingly.

There is furthermore the possibility that Mofolo "wrote" his text from the point of view of an oral account, where breaks between phrases are organised by means of breathing processes and practices. Conventional textual reading processes could disturb the continuous processes at work in oral narrative, and too many formal breaks such as with full stops might spoil the flowing train of thought that is typical of Mofolo's style. This possibility will be elaborated further in the course of this article.

\section{How consistently does the paragraph-length sentence occur?}

The short answer is, fairly consistently through the course of the narrative; however seldom with the same density as in the one-sentence paragraph I have just addressed. This is particularly the case when the paragraph-length sentence occurs as part of a longer paragraph where it is preceded and followed by "ordinary" full stop to full stop sentences. I wish to take the investigation a little further in order to get a fuller picture of the situation. I will work through the opening chapter of the novel from paragraph to paragraph (5-10) looking in particular at frequency, consistency and density of paragraph-length sentence usage.

The title of the chapter is "Nandi o kana Senzangakhona" (Nandi chooses Senzangakhona). The chapter opens with a broad geographical sketch of South Africa, zooms in on Bokone (KwaZulu), its flora and fauna, and describes the African nations of that area, in particular the different nations that made up what was later to become the AmaZulu, whose king was Senzangakhona. Senzangakhona's dilemma is that he is without a son and an heir to the kingdom. He plans to remarry and therefore organises a feast in order to meet young girls who would qualify. Nandi has already set eyes on him and he is delighted to be invited by her to dance. After the party he meets the girls in the valley, and suggests sex with Nandi, which she turns down at first, since it is against the rules of nature and nation. Later on, however, he succeeds and he carries out his plan. She falls pregnant and notifies the king, who hastily arranges to marry her so that the people do not realise that 
she has fallen pregnant before wedlock. The child is a boy, the king's first-born son; elated he sends word to the paramount king, Jobe. The boy is given the name Shaka/Chaka.

The opening paragraph of the novel is 18 lines long, consisting only of four full stop to full stop sentences. The opening sentence contains no semicolon. The second sentence contains two semicolon phrases; the third only one although it is six lines long. The fourth and last sentence again contains no semicolon phrase.

The second paragraph comprises only four lines, but does contain a semicolon phrase. The third paragraph is 20 lines long, consists of five full stop to full stop sentences, and contains seven semicolon phrases. No less than six of these semicolon phrases occur in the first full stop to full stop sentence. Unlike the example discussed above, not one of these six is introduced by a conjunction: one is introduced by the adverb hape (again); the remaining five are "conventional" sentences such as ke naha e talana ...; mobu ke selokwe ...; jwang ke seboku, tlanyane; metsi le makgwabo ...; dinoka di teng ...; (5) (it is a greenish land ...; the soil is black ...; the grasses are red grass, curl leaf; the water is marshy ...; there are rivers ...).

The fourth paragraph is 22 lines long. It consists of five full stop to full stop sentences with only two semicolon phrases, which occur in the third full stop to full stop sentence. The fifth paragraph is 17 lines long with five full stop to full stop sentences. There are four semicolon phrases, one in the first, one in the second, one in the third, and one in the fourth sentence.

Paragraph six is eight lines long, and consists of two full stop to full stop sentences, each containing one semicolon only. Paragraph seven is sixteen lines; there are only four full stop to full stop sentences, and only one semicolon phrase occurs in the third full stop to full stop sentence. The paragraph contains the prediction that the world was about to change after a new leader is born.

Paragraph eight is 21 lines long, and consists of six full stop to full stop sentences and altogether seven semicolon phrases, four of which occur in the second sentence, one in the third and two in the sixth full stop to full stop sentence. Paragraph nine is nine lines long; it consists of four full stop to full stop sentences, and there are three semicolon phrases all occurring in the first full stop to full stop sentence.

Paragraph ten is ten lines long and consists of only two full stop to full stop sentences with only one semicolon phrase occurring in each. Paragraph eleven is fourteen lines long, consists of three full stop to full stop sentences only and there are four semicolon phrases, the first containing two of them and sentences two and three one each. Paragraph twelve is fourteen lines, comprises four full stop to full stop sentences and six semicolon phrases of which three occur in the first and one in the second and two in the last full stop to full stop sentence.

Paragraph thirteen is fourteen lines with five full stop to full stop sentences and only one semicolon phrase in the penultimate full stop to full stop sentence. The last 
paragraph of the first chapter is six lines long, with two full stop to full stop sentences and only one semicolon phrase occurring in the first full stop to full stop sentence.

In Chapter One, then, the semicolon appears regularly and with varying but at times significant density. The reasons for opting for semicolon phrases instead of sentences may vary as well: enumerating objects and actions; enumerating consequential actions, concerns and reasons; or creating variations of style. The variation of style again points to the possibility that in Mofolo's creative mind oral tradition played its part in "miming the way he thought along pathways within a network" (Foley $5^{3}$, slightly adapted here). Mofolo might have chosen this option to compensate for the drawback of a "pre-structured linear narrative route" (see Buccitelli 232) he had to cope with in the age of printing.

Was Mofolo perhaps influenced by the style of (a) his own earlier novels; (b) the work of his contemporaries writing in Sesotho; or (c) by the world literature he had access to, such as the Bible and Victorian novelists Haggard and Corelli?

I wish at this stage to refer to Mofolo's other two novels; as can be expected, there are similarities in style and syntax. In both Moeti oa Bochabela (hereafter abridged to Moeti) and Pitseng we find similar broad, multi-thought processes and complex writing at work. However, there is less frequent use of semicolon phrases than in Chaka, especially their degree of succession in the same paragraph. I have worked through a sizeable paragraph from every chapter in both novels, with the purpose of finding a punctuation pattern that is similar to that of the one paragraph analysed above. In Moeti this is particularly the case: sizeable succession of semicolon phrases does occur, but infrequently.

In Pitseng the situation is a little different. On pages 34-6 there is a long paragraph with seven full stop to full stop sentences containing four successive semicolons in the third sentence, three in the fifth sentence and nine in the paragraph as a whole. However, a similar long paragraph occurs on pages 45-6 in which there are only three semicolons occurring in single sentences. Another long paragraph occurs on pages 188-9 where there are only two in a passage with eight full stop to full stop sentences.

These occurrences suggest the possibility that the use of semicolon phrases may largely depend on how the writer viewed the coherence of the information communicated. Until further research unearths convincing evidence, we are bound to conclude this brief excursion into Mofolo's earlier novels that the stylistic feature under consideration is fairly particular to his novel Chaka.

As regards possible influence by the style of Mofolo's contemporaries, these would have been Sekese, Segoete and Motsamai. Their novels appeared after his debut in 1907 with Moeti oa Bochabela. This book was serialised in the missionary newspaper Leselinyana la Lesotho during the previous year, which means that it was completed before or during 1906. Although Chaka was only published in 1925, research by 
D. P. Kunene (xii-xiii) shows that the manuscript had already been completed by 1909-10, that Mofolo left Morija in 1910, and that he never worked on it after his return to Lesotho, at least not before about 1922 It is unlikely that he read any work of his contemporaries before publication. Stylistic influences from them on him are therefore equally unlikely. If anything, the opposite might be a more likely possibility.

A. M. Sekese did publish a large number of articles on African history (Basotho and AmaZulu) in the newspaper Leselinyana la Lesotho, and I thought that it might be useful to consider the style in some of those. However, the exercise proved to be unfruitful for a clear reason: historical writings are factual and require a much more standard punctuation. I then searched even further back into Leselinyana, where I found a short story by Sekese in Leselinyana of 1 February 1887 under the title "Morekisi" (Name of a person). The punctuation here is quite conventional, with no feature that reminds one of Mofolo's punctuation, or a feature that could have had an influence on him. Finally I worked through Sekese's well-known Mekhoa ea Basotho which first appeared in 1893 and was most probably available to Mofolo. The finding here was the same as with his historical writings - factuality abounds, which does not appear in the free flowing style of a literary work such as Chaka.

E. Segoete's novel Monono appeared in 1910, the same year as Mofolo's second novel Pitseng. For stylistic parallels with Mofolo the search was again in vain. Much of this work consists of dialogue between Khitšane, Tim and other characters. Although the last few chapters are in fluent prose, they do not provide stylistic evidence that Mofolo could have been influenced by Segoete's way of punctuating his sentences.

E. Motsamai's Mehla ea malimo appeared in 1913. At this time Mofolo had already returned to Lesotho. I nevertheless did the same investigation as with the two other writers. This novel is written in fluent style with here and there the use of semicolons, but in no way comparable to Mofolo's.

What came to mind at this stage is the possibility that the subject matter as such might also have been a deciding factor for Mofolo. His novel Chaka, although highly fictionalised, deals with the life and times of a hero of history, which perhaps contributed to Mofolo's lofty or heroic style. If so, this possibility again points to likely influences from the oral past when heroes were honoured and criticised in the wellestablished tradition of praise poetry.

Turn now to possible influences on Mofolo from the Bible, H. Rider Haggard and Marie Corelli. Mofolo attended Bible School at the Morija station of the Paris Evangelical Mission Society (PEMS) during 1894 and thereafter worked as secretary to Alfred Casalis, the missionary who was in charge of the station during his time (1898-9). Mofolo's exposure to the scriptures is therefore beyond doubt.

It is a daunting task to explore the 66 books of the Bible in search of successive semicolons stretches reminiscent of Mofolo's style. Adding to the difficulty is the fact that the scriptures are presented in the form of verses each with its own num- 
ber-the presentation of which could discourage breaks of the size or implication of semicolon phrases. Random tests of well-known parts seemed to be inevitable for the purpose of this investigation. I started at usually well-trodden paths such as the story of the creation in Genesis 1; the Ten Commandments in Exodus 20; and the piece on the excellence of love in 1 Corinthians 13 . These explorations were not particularly fruitful.

What was said above about the style of historical and other factual writing largely applies to the Bible, despite the many narratives that characterise the different genres contained in it. Semicolon punctuation marks do occur but not in any conspicuous abundance or succession. There are parts of other books such as the Chronicles where higher densities of semicolon succession do occur. In II Chron. 34, verses 30-33, quite long verses occur in which I have counted four semicolon successions altogether: two in verse 30; and one each in 32 and 33. The opposite is also true. In a verse in the account of the Ten Commandments (Exodus 20: 10) no less than seven constructions also introduced by leha (though/although) occur, which Mofolo uses in two of his quoted semicolon phrases. However, the punctuation mark is only a comma, not a semicolon. The reason for this is that ordinary enumeration takes place here-not the multifunctional use of the semicolon phrase we have seen in the paragraph quoted from Mofolo's Chaka. Look at the example:

Empa letsatsi la bosupa ke phomolo ya Jehova. Modimo wa hao; o se ke wa etsa mosebetsi le o mong ka letsatsi leo, leha e le wena, leha e le mora wa hao, leha e le moradi wa hao, leha e le mohlanka wa hao e motona, leha e le motshehadi, leha e le kgomo tsa hao, leha e le moeti wa hao ya ka menyakong ya hao. (Bibele 85)

But the seventh day is the Sabbath of the Lord thy God: in it thou shalt not do any work, thou, nor thy son, nor thy daughter, thy manservant, nor thy maidservant, nor thy cattle, nor thy stranger that is within thy gates. (Holy Bible King James Version 66)

There are certainly both narrative and stylistic features that Mofolo could have gleaned from the Bible-such as the dignified tone of communicating the subject matter, as well as his dignified approach to characters and the reader. There are also situational correspondences in some scenes of the novel with the Bible, but this possibility does not apply to the topic we are dealing with here. Therefore, although Mofolo might have seen the semicolon in use in the Bible, the way he uses it is his own. The sections of the Bible I have explored suggest that he would not have found a similar textual topography there.

In his nine-page Introduction to F. H. Dutton's English translation of 1931, Sir Henry Newbolt (ix) mentions that Mofolo "had read all the religious and historical Sesuto (sic) books then published, some English historical books in South Africa, and some novels by writers like Rider Haggard and Marie Corelli". It was therefore 
self-evident to extend the exploration to these so-called Victorian authors (Gérard, "An African Tragedy" 39). Here again the novelistic outputs of both writers are so daunting that only sample tests from one novel by each writer were possible. In the case of Haggard the choice was made a little easier because he travelled southern Africa in the late nineteenth-century and based some of his novels on African history and legend. His Nada the Lily (1892) was a useful choice, partly because there are speculations that his heroine Nada could have inspired Mofolo to imagine his female character Noliwa, Chaka's fateful yet fictitious beloved. There is interesting subject matter that Chaka shares with Nada the Lily, such as parts of the history of the historical Shaka and the role legend plays in the two novels, both aspects that could be explored at another occasion. But the search for parallel topographical features in the layout of the paragraphs and the abundant use of successive semicolon phrases in particular, was yet again in vain. The layout in the book by Haggard is pretty conventional and no deviation from "ordinary" use of punctuation marks was picked up.

The case of Marie Corelli is different from that of Haggard. She writes in exuberant prose, and her attachment to the supernatural, as evident also in Mofolo's Chaka, stands out in her Barabbas (first published in 1893), which is the only of her novels I could lay my hands on. As is Mofolo, she too is fond of the long sentence but uses the en dash, sometimes preceded by a comma rather than the semicolon, to punctuate them. Look at this extract randomly chosen:

The hanging foliage drooped over them heavily, and seemed to draw them in and close them out of sight, - and although there was scarcely any wind to move the air, the thick leaves rustled mysteriously like ghostly voices whispering of some awful secret known to them alone - the secret of a tortured soul's remorse, - the indescribable horror of a sinner's death, self-sought in the deeper silence of their sylvan shadows.

(Corelli 217)

There are three en dashes but only the first dash-sentences can be called fully formed complex sentences; the others are parenthetical add-ons to fill in more information. Although this kind of topography by Corelli shows a similar kind of freedom as with Mofolo, I am not convinced that her style influenced him to follow her, even if by replacing the dashes with semicolons.

\section{Can current literary translation theories and practices contribute to a solution to the challenge?}

This question actually consists of two parts in that it refers to two separate issues, namely (a) literary translation theories and (b) literary translation practices. On the first part the answer is that literary translation theory can only serve as background to the understanding of the act of translation. The literature on literary translation is quite clear in this respect. Susan Bassnett, for example, sums it up as follows: "The 
purpose of translation theory, then, is to reach an understanding of the processes undertaken in the act of translation and, not, as is so commonly misunderstood, to provide a set of norms for effecting the perfect translation" (43; italics added). In this respect theory will assist in understanding what I have been exploring in this article-highlighting the kind of decisions the translator has to take during the process of translating, but not with a blue print for how the problem of the "topography of the page" should be handled. The set of norms to which Bassnett refers falls within the domain of the second part of our question, namely the practice of literary translation itself. Against this background it will not help us to pursue the theory of translation much further.

The second part of the question will bring me nearer to the essence of my concerns in this article; yet there is a reservation even in this respect. The problem applies to an almost minuscule aspect of the theatre of literary translation practice, namely how semicolon phrases should be handled in translation, especially when they are appearing in extended successive sequences. Here again a key guideline is the nearest I could get. As Leonardo Bruni (1370-444) puts it: "For this is the highest rule of translation: that the shape of the original text should be kept as closely as possible, so that understanding does not lose the words any more than the words themselves lose brilliance and craftsmanship" (qtd. in Sánchez 23).

Useful to my argument is the concept "shape", which certainly includes the topography of the page and as part of this the punctuation, and thus also the use of the semicolon by Mofolo. Translators of this work have largely been faithful to the contents of the book but they have not followed Mofolo's punctuation in all respects. Another way of putting this is that translators strive for "equivalence" (Nida 120-45, 241-79; Bassnett 30-3; Haque 107). However, my experience is that the ideal of equivalence becomes quite problematic in languages from different language families; it is in fact hardly attainable. As an alternative the translation literature is helpful by suggesting the idea of an "interpretive resemblance" (Folgado 111-3). The closest possible resemblance does indeed provide the translator with substantial space to move in, and appears to be a much more attainable guideline.

Conclusion: How should Mofolo's sentence design be approached in translation? The answer to this question gradually became clear as I worked my way through the argument of this article. Firstly, by stating that the challenge of the sentence design arises from the so-called paragraph sentence, and then narrowing it down to what I have called the semicolon phrase; secondly, by comparing a typical semicolon phrase of Mofolo with what five translators made of it; thirdly, by replying to the question whether Mofolo would deliberately have challenged conventional punctuation rules; fourthly, by scanning chapter 1 of the novel, determining how consistently Mofolo worked this way; fifthly, by investigating whether Mofolo may have been 
influenced by what he did in his earlier novels, those of his contemporaries, or by the punctuation in the Bible as well as some of the works of the Victorian novelists H. Rider Haggard and Marie Corelli; and sixthly how literary translation theory and practice could assist in approaching the challenge.

No clear answer such as to "do this" or "don't do that" can at this stage be provided. The clearest guideline is Bruni/Lefevere's advice that the shape of the original should be maintained as closely as possible. Shape no doubt includes the topography of the page and the author's punctuation of it. The investigation also found that Mofolo could have been influenced by the oral tradition and that his use of the semicolon phrase may have sought to maintain aspects of the tradition. This possibility assisted me a great deal in taking decisions with regard to the punctuation used in the Afrikaans translation: if Mofolo made use of the semicolon phrase to resemble narrative practices of the oral tradition, it equally makes sense for the translator to shape her/ his punctuation in a manner that resembles rather than equals Mofolo's design.

From the ways in which the translators of Mofolo have operated, it seems justifiable to conclude that punctuation and the use of punctuation marks are indeed more negotiable than the narrative text itself. My concerns about this negotiability of the punctuation, including Mofolo's use of the semicolon, drove me to attempt a new translation of the work-retaining the shape of the original as consistently as possible, while throughout respecting the conventions of Afrikaans, the TL. Unambiguity and simplicity were collaborating guiding factors in all decisions on how the sentence design in Chaka as source text should be approached. Mofolo deserves to be approached with respect, in accordance with the ethics of literary translation.

Notes

1. See Mofolo, Chaka ([Lesotho Orthography], 2014): pages 14, 20, 21, 30, 33, 35, 51, 55-6, 58, 62, 63, 68, $73,95,96,107,112,113$ (twice), 118, 119-20, 141, 152-3, 159 and 164 .

2. All quotations from this edition I have transcribed into the RSA orthography of Sesotho.

3. Knowledge of, access to, and quotations from Foley's work were via Buccitelli's review of it that appeared in Journal of American Folklore.

\section{Works Cited}

Bassnett, S. Translation Studies. London: Routledge, 2004 [1980].

Bibele e halalelang. Kaapstad: Britse en Buitelandse Bybelgenootskap, 1961.

Buccitelli, A. B. "Book Review of Oral Tradition and the Internet by John Miles Foley." Journal of American Folklore 128.508 (2015): 231-3.

Corelli, M. Barabbas: A Dream of the World's Tragedy. London: Methuen, 1964 [1893].

Foley, J. M. Oral Tradition and the Internet: Pathways of the Mind. Urbana: U of Illinois P, 2012.

Folgado, V. L. "Literary Translation as a Cognitive Activity." Aspects of Literary Translation: Building Linguistic and Cultural Bridge in Past and Present. Ed. E. Parra-Membrives, M. A. G. Peinado, \& A. Classen. Tübingen: Narr Verlag, 2012. 101-19.

Gérard, A. S. "An African Tragedy of Hubris: Thomas Mofolo's Chaka." Sense and Sensibility in TwentiethCentury Writing. Ed. Brom Weber. Carbondale: Southern Illinois U P. 1970. 39-57. Four African Literatures: Xhosa, Sotho, Zulu, Amharic. Berkeley: U of California P, 1971.

Haggard, H. R. Nada the Lily. London: Macdonald. 1949 [1892]. 
Haque, M. Z. "Translating Literary Prose: Problems and Solutions." International Journal of English Linguistics 2.6 [2012]: 97-111.

Holy Bible, King James Version. Cape Town: Bible Society of South Africa, 1962.

Kunene, D. P. “Introduction.” Thomas Mofolo. Chaka-A New Translation of the Famous Novel. Trans. D. P. Kunene. London: Heinemann, 1981. xi-xxiii.

Lefevere, A. Ed. Translation: Culture/History: A Source Book. London: Routledge, 1992.

Mofolo, T. Chaka. (Lesotho Orthography). Morija: Morija Sesuto Book Depot, 1957 [1925].

. Chaka. (Lesotho Orthography). 4th rprt. Morija: Morija Sesuto Book Depot, 2014 [1925].

Chaka. (RSA Orthography). Morija: Morija Sesuto Book Depot, 1973 [1925].

. Chaka, an Historical Romance. Intr. Sir Henry Newbolt. Trans. F. H. Dutton. London: O U P, 1931.

Chaka-A New Translation of the Famous Novel. Trans. D. P. Kunene. London: Heinemann, 1981.

Chaka—Die Nuwe Afrikaanse Vertaling. Trans. C. Swanepoel. 2015. Manuscript.

. Chaka, une épopée Bantoue. Trans. V. Ellenberger. Paris: Gallimard, 1940.

. Chaka Zulu. Trans. Peter Sulzer. Zürich: Manesse Bibliothek der Weltliteratur, 1988.

. Moeti oa Bochabela. Morija: Morija Sesuto Book Depot, 1980 [1907].

. Pitseng. Morija: Morija Sesuto Book Depot, 1930 [1910].

. Tjhaka. Trans. C. Swanepoel. Kaapstad: Tafelberg-Uitgewers, 1974.

Motsamai, E. Mehla ea Malimo. Morija: Morija Sesuto Book Depot, 1932 [1913].

Newbolt, H. “Introduction.” Thomas Mofolo. Chaka, an Historical Romance. Intr. Sir Henry Newbolt. Trans. F. H. Dutton. London: O U P, 1931. vii-xv.

Nida, E.A. Bible Translation. London: United Bible Societies, 1961 [1947].

Sánchez, M. T. The Problems of Literary Translation: A Study of the Theory and Practice of Translation from English into Spanish. Bern: Peter Lang, 2009. 17 Aug 2015. < https://books.google.co.za/book?id=WePOuqUy $\mathrm{oSAC} \&$ printsec $=$ frontcover $=$ onepage $\& \mathrm{q} \& \mathrm{f}=$ false $>$.

Segoete, E. Monono ke Moholi ke Mouane. Morija: Morija Sesuto Book Depot, 1967 [1910].

Sekese, A.M. "Morekisi". Leselinyana la Lesotho1 (1887): 3-4.

. Mekhoa ea Basotho. Morija: Morija Sesuto Book Depot, 1968 [1893]. 